\title{
A model for experimental infections with Vibrio (Listonella) anguillarum in first feeding turbot (Scophthalmus maximus L.) larvae under hatchery conditions
}

\author{
Miquel Planas*, María Pérez-Lorenzo, José Antonio Vázquez and José Pintado \\ Instituto de Investigaciones Marinas (C.S.I.C.), Eduardo Cabello 6, 36208 Vigo, Spain \\ *corresponding author \\ phone: +34986214457 \\ fax: +34 986292762 \\ e-mail: mplanas@iim.csic.es
}




\section{SUMMARY}

Vibriosis is one of the main causes of mortality in all stages of fish. In larvae, further improvements on the control and knowledge of bacterial diseases require the development of models for experimental infections. A reproducible model for in vivo infections of first feeding turbot (Scophthalmus maximus) larvae with the pathogen Vibrio (Listonella) anguillarum is described. Experimental challenges were carried out under hatchery conditions considering different ways of delivery of V. (Listonella) anguillarum strain 90-11-287 serotype O1 to turbot larvae: via rotifers (orally) and via water of the larval rearing tanks (bath). The effect of the supernatant of the bacteria culture was also considered and discussed. The model proposed is based on the incorporation of the bacteria into previously enriched rotifers and the delivery to the larvae during the rotifer feeding period. The effect of infections was already evident 24-72 h after the first challenged day. Final mortalities (day 8-14) in infected larvae were 56$72 \%$ with respect to unchallenged larvae. Mortalities achieved by applying the protocol of infection are reliable, reproducible and adequate for experimental purposes. The model of infection via rotifers proposed in this study is a useful tool for experimental purposes in the larval rearing of marine fish.

Keywords: Infection model, Larval rearings, Vibrio anguillarum, Rotifer, Turbot, Scophthalmus maximus. 


\section{INTRODUCTION}

During years, efforts have been made on the reduction of diseases caused by Vibrio. This genus has been associated with severe disease in fish culture (Egidius, 1987; Toranzo et al., 1987, 1990, 1993; Austin et al., 1995; Diggles et al., 2000) and Vibrio anguillarum has been often reported as the cause of severe infections in cultured marine fish. Turbot (Scophthalmus maximus L.) is one of the species particularly affected by V. anguillarum (Egidius, 1987; Toranzo et al., 1987; 1993, 1994; Toranzo and Barja, 1990; Myhr et al., 1991; Chair et al., 1994; Larsen et al., 1994; Grisez et al., 1996).

Several authors suggested two ways of entry for Vibrio in fish: via live food (Masumura et al., 1989; Muroga et al., 1987, 1990; Chair et al., 1994; Grisez et al., 1996) or via skin, gills and anus (Chart and Munn, 1980; BaudinLaurencin and Germon, 1987; Kanno et al., 1989).

Literature focussed on the development of models for experimental infections in fish larvae, particularly turbot, is very scarce (Chair et al., 1994; Munro et al., 1995; Grisez et al., 1996). Reliable experimental models for further studies with larvae on diseases caused by bacteria would be helpful in the assessment of the virulence of isolates and the evaluation of methods or treatments of prevention (Roque et al., 1998).

The present paper describes for the first time a technique developed for reproducible experimental infections via rotifers with a strain of Vibrio anguillarum in standard conditions in the very early stages of turbot larvae (from first feeding up to day 8-14 posthatching). The effect of oral (via rotifers) and bath (via water of larval tanks) administrations of the bacteria during the rotifer feeding period is also discussed.

\section{MATHERIALS AND METHODS}

\section{Bacterial culture conditions and growth}

Vibrio (Listonella) anguillarum strain 90-11-287 serovar O1 was isolated from rainbow trout (Oncorhynchus mykiss) in Denmark (Skov et al., 1995) and delivered by Prof. H. Birkbeck (Institute of Biomedical and Life Sciences, Glasgow, UK). Serovar O1 is the most important in adult turbot (Larsen et al., 1994) and may cause septicaemia in the larvae (Grisez et al., 1996). The virulence of this isolate by immersion $\left(10^{3}-10^{7} \mathrm{CFU} \mathrm{ml}{ }^{-1}\right)$ on non-feeding turbot larvae was previously reported by Hjelm et al. (2004).

For long-term preservation, the strain was kept at $-80^{\circ} \mathrm{C}$ in TSB $\left(30 \mathrm{~g} \mathrm{l}^{-1}\right)$ with glucose $\left(5 \mathrm{~g} \mathrm{l}^{-1}\right)$, skimmed milk $(20 \mathrm{~g}$ $\mathrm{l}^{-1}$ ) and glycerol $\left(40 \mathrm{~g} \mathrm{l}^{-1}\right)$. The bacterium was initially grown during 24 hours in $10 \mathrm{ml}$ of marine broth (MB, Difco) 
on a rotary shaker at $200 \mathrm{rpm}$ and $22^{\circ} \mathrm{C}$. Then, an aliquot of $1 \mathrm{ml}$ of the culture was added to a flask with $100 \mathrm{ml}$ of MB, grown during 24 hours and sub-cultured twice under the same conditions. For the separation of the bacteria from supernatants, aliquots of the culture were centrifuged at $5000 \mathrm{rpm}$ for $15 \mathrm{~min}$, washed and re-suspended to the appropriate cell densities in sterile sea water. Growth was monitored both by measurement of the optical density (700 nm) and by serial dilution and plate counting.

\section{Turbot larval rearing}

Newly hatched larvae (day 0) of turbot were obtained from Stolt Sea Farm (Merexo, Galicia, Spain). Two days old larvae were transferred (30-35 larvae $\mathrm{l}^{-1}$ ) to $60 \mathrm{l}$ tanks. Tanks were previously disinfected with $1 \%$ Dismozon Pur (Bode). The temperature was progressively raised from 15 to $18^{\circ} \mathrm{C}$ during the following 3 days and the light (continuous day light provided by $30 \mathrm{w}$ fluorescent lamps) intensity at the surface of the larval tanks was adjusted to $3.5 \mu \mathrm{E} \mathrm{sec}^{-1} \mathrm{~m}^{-2}$. The larvae were fed on enriched rotifers from day 3 until day 10 . The density of rotifers was daily adjusted to 3-5 rotifers $\mathrm{ml}^{-1}$. The water of the rearing tanks was partially (30-40\%) changed every 2 days from first feeding with a subsequent addition of $2.5 \mathrm{l}$ of $\mathrm{I}$. galbana culture. The bottom of the tanks was siphoned daily to remove and count dead larvae. Samples of larvae were also taken at the end of the experiments for dry weight analyses. Dry weights were obtained after collecting 100 larvae on $150 \mu \mathrm{m}$ mesh, washing with tap water and drying at $60^{\circ} \mathrm{C}$ for $48 \mathrm{~h}$. All the tanks were conducted by duplicate.

\section{Challenge P: Pathogenicity of $V$. anguillarum strain assayed in juvenile turbot}

The pathogenicity of $V$. anguillarum strain and the effect of bacteria culture supernatant were assayed in turbot juveniles (Challenge P). Turbot juveniles (5-8 g), provided from Stolt Sea Farm (Merexo, Galicia, Northwest Spain), were maintained at $17^{\circ} \mathrm{C}$ in sea water under aeration and fed daily on a commercial diet. After a week of acclimatizing, four groups of 10 juveniles each were distributed into four $60 \mathrm{l}$ tanks (10 juveniles per tank) and intraperitonealy injected with $0.1 \mathrm{ml}$ containing:

Control: Ringer’s solution (Ringer’s tablets, Merck).

Low: $10^{4}$ CFU of $V$. anguillarum without supernatant (bacteria cultures centrifuged and washed)

High: $10^{5}$ CFU of V. anguillarum without supernatant (bacteria cultures centrifuged and washed)

High+: $10^{5}$ CFU of V. anguillarum with supernatant (cells not washed nor centrifuged)

Turbot juveniles were maintained and fed on an inert diet for 11 days. Mortalities were recorded daily in each tank and were considered to be due to the inoculated $V$. anguillarum if the bacterium was recovered in pure culture from 
dead fish. Relative percent infection (RPI) was calculated as a ratio of percentage of mortalities in the infected groups to the percentage mortalities in the control group (1-\% infected mortality/\% control mortality x 100) (Amend, 1981).

\section{Challenge R: Incorporation of $V$. anguillarum into rotifers}

Challenge R1: Long term incorporation (axenic rotifers). Bacteria-free Isochrysis galbana and rotifer cultures were performed at $23^{\circ} \mathrm{C}$ during 6 days using a modification of the chemostat system described by Scott (1980). Microalgae and rotifers were inoculated in $5 \mathrm{l}$ flasks (1 flask with $3.5 \times 10^{5}$ cells and 4 flasks with 2 rotifers ml ${ }^{-1}$ respectively) containing sterile sea water. Another flask containing sterile Walne media was used to supply nutrients to the microalgae. The flasks were connected to a system composed of a peristaltic pump (Ismatec IPN-8) and twostop silicone tubings (Ismatec, SC0102) which permitted a daily supply of Walne media to the microalgae and microalgae to rotifers. Two flasks of the rotifer cultures were inoculated once with $V$. anguillarum $\left(10^{7} \mathrm{CFU} \mathrm{m}^{-1}\right)$ and the other two flasks remained as controls. Samples of rotifers were daily taken for rotifer growth calculations.

Challenge R2: Long term incorporation (non-axenic rotifers). Rotifers were filtered and washed, and then bathed (400 rotifers $\left.\mathrm{ml}^{-1}\right)$ in $5 \mathrm{l}$ of sea water containing $V$. anguillarum $\left(10^{8} \mathrm{CFU} \mathrm{ml}^{-1}\right)$ for 3 hours at $23^{\circ} \mathrm{C}$. Subsequently, 5 l of I. galbana culture ( $3.5 \times 10^{6}$ cells $\left.\mathrm{ml}^{-1}\right)$ were added daily and the rotifers were enriched for 3 days. Samples of rotifers and water were taken for microbiological analysis.

Challenge R3: Short-term incorporation (non-axenic rotifers). Incubation of $V$. anguillarum with rotifers was assayed by enriching the rotifers (200 rotifers $\mathrm{ml}^{-1}$ ) on Isochrysis for $24 \mathrm{~h}$ in $10 \mathrm{l}$ tanks at $23^{\circ} \mathrm{C}$. Following the enrichment, the rotifers were washed, filtered and transferred (200 rotifers $\mathrm{ml}^{-1}$ ) into $5 \mathrm{l}$ buckets containing sea water with $V$. anguillarum $\left(10^{8} \mathrm{CFU} \mathrm{ml}{ }^{-1}\right)$. The rotifers were maintained in this bacterial suspension for 3 hours and then filtered and rinsed again. Samples of rotifers were taken at the start and at the end of the enrichment on I. galbana and at the end of the maintenance in the bacterial suspension.

In all incubation challenges, the bacteria were added together with the supernatant of the culture (cells not washed nor centrifuged).

\section{Challenge S: Effect of the supernatant of $V$. anguillarum}


This challenge was conducted in order to ascertain the effect on the larvae of the addition of supernatant of $V$. anguillarum cultures in the enrichment of rotifers. Turbot larvae were fed on rotifers according to the following treatments:

Control: Rotifers enriched on Isochrysis for $24 \mathrm{~h}$.

R: At days 3, 5 and 7, the rotifers were previously enriched on Isochrysis for $24 \mathrm{~h}$ and subsequently maintained for 3 hours in two 51 buckets $\left(18^{\circ} \mathrm{C}\right.$; 200 rotifers $\left.\mathrm{ml}^{-1}\right)$ with addition of $10^{8} \mathrm{CFU} \mathrm{ml}{ }^{-1}$ of $V$. anguillarum without culture supernatant. The other days, the larvae were fed as for controls.

$\mathrm{R}+$ : Rotifers as for treatment $\mathrm{R}$ but with addition of not washed (with supernatant) $\mathrm{V}$. anguillarum. The volume of bacteria culture supernatant added was to $175 \mathrm{ml}$.

\section{Challenge L: Experimental infections of turbot larvae}

Several challenges (L1, L2, L3a, L3b and L3c) were assayed for testing different ways of delivery of V. anguillarum (Table 1). All the tanks were conducted by duplicate. The following treatments were applied:

Control: Turbot larvae were reared as described previously in $60 \mathrm{l}$ tanks. The larvae were fed on rotifers enriched on I. galbana for $24 \mathrm{~h}$ (Rotifer C).

W: Supernatant-free $V$. anguillarum were added $\left(10^{6} \mathrm{CFU} \mathrm{ml}^{-1}\right)$ to the water of the larval tanks at larval first feeding.

$\mathrm{R}+$ : The larvae were fed on rotifers previously enriched on I. galbana for $24 \mathrm{~h}$ and then bathed in a suspension of V. anguillarum $\left(10^{8} \mathrm{CFU} \mathrm{ml}{ }^{-1}\right)$ with supernatant for 3 hours (Rotifer $\mathrm{R}+$ ).

$\mathrm{R}+\mathrm{W}+$ : The larvae were fed on Rotifers $\mathrm{R}+$, and not washed $V$. anguillarum $\left(10^{7} \mathrm{CFU} \mathrm{ml}{ }^{-1}\right)$ was delivered to the water of the larval tanks.

\section{Microbiological methods}

Samples from larvae, rotifers and water were taken at different time intervals (Table 4)). Ten larvae or 400 rotifers were separated using a $250 \mu \mathrm{m}$ or $30 \mu \mathrm{m}$ Nylon mesh, respectively. Larvae were anaesthetised with 3-aminobenzoic acid ethyl ester (MS22, Sigma). Larvae and rotifer were washed with sterile sea water and mashed. Water and homogenized larvae or rotifer samples were serially diluted in sterile sea water, plated into Marine Agar (MA, Difco) and incubated for 3 days at $20^{\circ} \mathrm{C}$ in the dark. Plates with 30 to 300 colonies were counted. For Vibrio identification, appropriate dilutions were replica-plated from MA onto TCBS plates (Scharlau), incubated one day at $20^{\circ} \mathrm{C}$ and colonies were counted. This replica-plated method avoided the underestimation of Vibrio counts, observed 
in direct counting on TCBS (data not shown). Colonies of Vibrio anguillarum and other Vibrio strains were recognized morphologically. V. anguillarum was identified using the agglutination test MONO-VA (Bionor, Norway). The later were carried out at the University of Glasgow by Dr. T.H. Birkbeck and Dr. H. Duncan.

\section{Numerical methods}

Fitting of data and parametric estimations calculated from the results were carried out by minimisation of the sum of quadratic differences between observed and model-predicted values, using the non linear least-squares (quasiNewton) method provided by the macro 'Solver' of the Microsoft Excel XP spreadsheet. Statistica 6.0 (StatSoft, Inc. 2001) was used to demonstrate the significance of the parameters estimated by the adjustment of the experimental values to the proposed mathematical models. The two statisticians (parameters) corresponding to the logistic model used (1) were: $K$ (maximum mortality) and $r_{m}$ (maximum specific mortality rate).

\section{Statistical analyses}

Differences in final survivals and weights of larval challenges were analysed using one-way analysis of variance (ANOVA) and Student-Newman-Keuls multiple range test at 5\% level of significance. Data of survivals were previously transformed as arc sin (square root).

\section{RESULTS}

\section{Challenge P: Pathogenicity of V. anguillarum strain}

Infections of turbot juveniles with Vibrio and supernatant (treatment High+) resulted in a huge and sudden mortality (60\%) after 3 days of treatment. Mortalities increased up to 70\% afterwards and remained constant until day 11. Dead fish showed haemorrhagic lesions on the skin and at the base of the fins. Pathogenicity of the same doses of Vibrio (10 $0^{5}$ CFU) but washed (treatment High) was smaller (30\% mortality at day 11) and delayed. Finally in treatment Low, inoculations of washed Vibrio at the lowest dose $\left(10^{4} \mathrm{CFU}\right)$ revealed a lack of pathogenic effect in juveniles throughout the experimental period. As for controls, all the animals were alive at day 11 . The relative percent infection (RPI) at day 11 were 0, 30 and 70\% for groups Low, High and High+, respectively.

\section{Challenge R: Incorporation of Vibrio anguillarum into rotifers}

Long term maintenance of rotifers in the presence of high doses of V. anguillarum $\left(10^{7}-10^{8} \mathrm{CFU} \mathrm{ml}^{-1}\right.$; challenges R1 and R2) resulted in a progressive mortality of the rotifers after 24 h. The initial numbers of rotifers were almost 
constant during the first day, but total numbers decreased to $40-60 \%$ in the following day. By day 3, only 10 and $50 \%$ of rotifers remained alive in challenges R1 and R2, respectively.

In Challenge R1 (initial axenic rotifers), bacteria numbers in rotifers were only analysed at day 3. By then, the level of $V$. anguillarum per rotifer was $6 \times 10^{5} \mathrm{CFU}$. In the water, $V$. anguillarum was able to maintain the initial levels for at least 3 days.

In Challenge R2 (non-axenic rotifers), V. anguillarum was the dominant Vibrio in water at the beginning of the experiment and only one strain of Vibrio (Vibrio 2) was identified in rotifers. This strain was also present in water before $V$. anguillarum addition. $V$. anguillarum could only be identified in rotifers in samples taken $3 \mathrm{~h}$ after the beginning of the challenge. At this moment, this bacterium accounted for 70\% and $95 \%$ of total Vibrio in water and rotifers, respectively. Another strain, Vibrio 3, accounted for the remaining percentage. V. anguillarum could not be identified, both in water and in rotifers, at 21 and 45 hours. By then, the dominance corresponded to Vibrio 2 and 3. V. anguillarum, Vibrio 2 and Vibrio 3 were differentiated morphologically when grown in TCBS.

In challenge, R3, short-term incorporation of non-washed $V$. anguillarum in rotifers $\mathrm{R}+$ was successful without rotifer mortality. V. anguillarum reached a level of $2 \times 10^{3} \mathrm{CFU}$ rotifer ${ }^{-1}$, which corresponded to 99 and $61 \%$ of total Vibrio and total bacteria, respectively. Total numbers of bacteria in rotifers $\mathrm{R}+$ was 2.6-folds higher than in rotifers enriched only on Isochrysis (Rotifer Control).

\section{Challenge S: Effect of the supernatant of $V$. anguillarum}

Thee lowest larval survival ( $35 \pm 2 \%$ at day 10) was achieved when the larvae were fed on rotifers submitted to $V$. anguillarum with supernatant (treatment $\mathrm{R}^{+}$) (Fig. 1) (Table 2). Higher survivals (58 \pm 3 ) were obtained when $V$. anguillarum were delivered washed to rotifers (treatment R). Dry weights were also consistent with survivals. The use of $V$. anguillarum with supernatant resulted in lower growth.

The microbiological analysis of water at day 9 posthatching showed similar levels of $V$. anguillarum in treatments R and $\mathrm{R}+$. However, in larvae V. anguillarum was only found in tanks $\mathrm{R}+$, where the highest mortality was recorded (Fig. 2).

\section{Challenge L: Experimental infections of turbot larvae}

In challenge L1, direct delivery of washed Vibrio to the water of the larval tanks conducted to high mortalities (Table 3) but with a high standard deviation of the mean ( $58 \% \pm 47$ ) due to a crash in one of the tanks during the last night of the experiment. In the other tank, mortality was the same than in controls (about 20\%). 
When the larvae received $V$. anguillarum with culture supernatant both via rotifers and via water of larval tanks (treatment $\mathrm{R}+\mathrm{W}+$ in challenge L2), mortality (Table 3) increased enormously (94 \% \pm 2 at day 9) as compared to controls or to larvae fed on infected rotifers only (treatment $\mathrm{R}+$ ).

The levels of $V$. anguillarum in water and turbot larvae are given in Table 4. In challenge L1, after a single addition of $V$. anguillarum to the water $\left(10^{6} \mathrm{CFU} \mathrm{ml}^{-1}\right)$ at day 3 posthatching, the level of the pathogen in the water decreased continuously until its disappearance at day 7 posthatching. The numbers of total bacteria remained constant throughout the experiment $\left(10^{6} \mathrm{CFU} \mathrm{ml}^{-1}\right)$. However, in challenge $\mathrm{L} 2$ the continuous addition of $V$. anguillarum both via rotifers and via water at days 3,5 and 7, allowed the pathogen to maintain the level in water at $10^{3} \mathrm{CFU} \mathrm{ml}^{-}$

${ }^{1}$ at day 8 posthatching. In both challenges, V. anguillarum was found in larvae only at day 4 posthatching $\left(10^{1} \mathrm{CFU}\right.$ larva $^{-1}$ in treatments $\mathrm{W}$ and $\mathrm{R}+\mathrm{W}+$ and $10^{2} \mathrm{CFU}$ larva $^{-1}$ in treatment $\mathrm{R}+$ ).

\section{Experimental infection model}

From the previous experiments, conditions for obtaining intermediate mortalities with low variability were established. Those conditions were: incorporation in rotifers of $V$. anguillarum with culture supernatant (treatment $\mathrm{R}+$ ). Three challenges (L3a to L3c) were conducted under those conditions.

Microbiological analysis in challenges L3a and L3b showed that there were no major differences between control tanks and treated tanks in the progress of the total bacteria and total Vibrio, both in water and in turbot larvae (data not shown). The levels of $V$. anguillarum in water and turbot larvae are given in Table 4. In water, the levels of $V$. anguillarum increased up to $3 \times 10^{3} \mathrm{CFU} \mathrm{ml}{ }^{-1}$ until day 5 and remained constant thereafter. V. anguillarum was dominant among Vibrio but accounted for a low proportion of total bacteria. In larvae, V. anguillarum followed the pattern observed in water. However, the bacterium was not identified at day 5 in challenge L3b, probably due to the high amount of other Vibrio strains present in the samples which made difficult the isolation and identification of $V$. anguillarum.

Although ages of larvae at the end of the experiments were different among challenges, mean final mortalities in challenged larvae were consistently higher than in unchallenged larvae, independently of the age of the larvae, accounting for $85-92 \%$. These values represented $56-72 \%$ with respect to mortalities achieved in non-challenged larvae. Furthermore, final weights were also lower in challenged larvae although not statistically different from controls (Table 3). 
An overview on the effect of the model proposed is given in figure 3 with pooled data from challenges L2, L3a, L3b and L3c. The figure shows a linear relationship between the final survivals achieved in controls and in larvae challenged with $V$. anguillarum according to treatment $\mathrm{R}+$. This relationship was found for both absolute and particularly relative to controls survivals.

\section{Mortality kinetic analysis}

Kinetics of larval mortalities presented sigmoid profiles with final asymptote at infinite time (Fig. 4). For the adjustment of these experimental data three different mathematical models were used: Gompertz, von Bertalanffy and logistic. The best correlation between expected and observed values ( $\mathrm{r}=0 \cdot 998-0 \cdot 999)$ was found for the logistic model. Consequently, mortality kinetics of larvae were adjusted to a logistic model (Fig. 4):

$$
M=\frac{K}{1+b e^{-r_{m} t}} \text {, where: }
$$

M: mortality (percentage) of Scophthalmus maximus L. larvae.

$K$ : maximum mortality (dimensions: $M$ )

$b$ : fitting parameter (dimensionless)

$r_{m}$ : maximum specific mortality rate (dimensions: $t^{-1}$ )

For challenges L2, L3a, L3b and L3c, experimental means of unchallenged (C) and challenged (R+) larvae with their corresponding confidence intervals of the means $(\alpha=0 \cdot 20 ; v=3)$ and the asymptotic parameter or maximum mortality $(K)$ are shown in figure 4. Patterns of accumulated mortalities obtained for the three challenges were very similar. A clear pathogenic effect of $V$. anguillarum was observed in larvae from 1-3 days after the first delivery of infected rotifers (days 5-7 posthatching) until the end of the experiments. In all cases, maximum mortalities and maximum specific mortality rates of challenged larvae $\left(K(\mathrm{R}+)\right.$ and $r_{m}(\mathrm{R}+)$, respectively) were higher than in controls $\left(K(\mathrm{C})\right.$ and $r_{m}(\mathrm{C})$, respectively).

\section{DISCUSSION}

Fish dead in the virulence challenge performed in turbot juveniles with $V$. anguillarum strain 90-11-287 serotype O1 showed haemorrhagic lesions on the skin and at the base of the fins, similarly to the symptoms reported previously in flatfishes suffering vibriosis (Horne et al., 1977; Lupiani et al., 1989; Lee et al. 1991; Diggles et al., 2000). 
Abdominal swelling was not observed. It was found that mortalities were dependent on the level of the dose as well as on the administration or not of the supernatant of the bacterial culture in the intraperitoneal injection. The lack of supernatant and the use of low doses of bacteria resulted in a decrease of mortality. The test finished at day 11 postinoculation and it is possible that higher mortalities could be achieved with longer periods of experimentation. The virulence of $V$. anguillarum was evident, with a final mortality of $70 \%$ (day 11) in fish challenged with $10^{6} \mathrm{CFU}^{-} \mathrm{ml}^{-}$ ${ }^{1}$ of the bacteria with culture supernatant. Hjelm et al. (2004) reported up to 80\% mortality in non-feeding turbot larvae exposed by immersion to the same isolate at concentrations ranging from $10^{3}$ to $10^{7} \mathrm{CFU} \mathrm{ml}^{-1}$. Therefore, the test fulfilled the EU guidelines with mortality above $70 \%$ in at least 28 days (EU, 1993).

Supernatants of bacteria cultures include ECPs (extra cellular products) from the bacteria. It is known that ECPs from some Vibrio are toxic to some cellular lines (TV-1 and TF) in turbot (Villamil et al., 2003) and that ECPs from $V$. pelagius are highly toxic to turbot post-larvae $(0.4 \mathrm{~g})$ (Villamil, 2002). Similarly, it has been reported that $V$. anguillarum ECPs cause severe fish mortalities in Japanese eels and rainbow trout (De la Cruz and Muroga, 1989; Santos et al., 1992). The effect of ECPs can also be dependent on the variability between V. anguillarum isolates. In our laboratory, previous infections carried out with addition of a different strain of V. anguillarum (DC11R2) (10 ${ }^{6}$ CFU ml-1), supernatant- free, into larval tanks of turbot induced to $100 \%$ mortality at day 10 (unpub. data). The challenge performed to verify the effect of supernatant of V. anguillarum cultures in turbot larvae (Challenge S) seems to show an additive effect of bacteria and supernatant. However, it should be considered that, removing supernatant implies centrifuging and washing of bacteria. This could induce stress to the bacterium and a potential loss of pathogenicity.

Data from challenge L1 suggest that the delivery of supernatant-free $V$. anguillarum to the water of the rearing tanks could be sufficient to induce high mortalities. However, the high standard deviation observed when V. anguillarum was added only to water (Table 3) suggest a less reliable model than oral delivery through rotifers. In our study, performed on very early stages of turbot larvae, the highest mortalities were achieved when V. anguillarum was delivered to the water and the larvae were fed on rotifers containing bacteria (Challenge L2). Anyway, incorporation in rotifer of $V$. anguillarum reproduced an infection pattern with intermediate mortalities.

There are several hypotheses about the route of entry of $V$. anguillarum in fish. Oral delivery of the pathogen by live food (Artemia) has been reported to induce high mortalities in turbot post-larvae (Chair et al., 1994; Grisez et al., 1996). Grisez et al. (1996) reconstructed the infection route followed by the bacteria in oral challenge with turbot. 
According to these authors, the bacteria, previously incorporated in Artemia nauplii, were released in the anterior part of the intestine. There, bacteria were transported through the intestinal epithelium by endocytosis and released in the lamina propia. Ultimately, bacteria were transported by the blood to the different organs. However, these results seem to be somewhat conflicting with those of Olsson et al. (1996) in oral and rectal challenges performed in turbot fingerlings. These authors proposed that Vibrio cells penetrate the intestinal mucus but epithelial cell penetration or endocytosis was not evident. Another hypothesis is that $V$. anguillarum enters into the fish through the skin, the gills or the anus (Chart and Munn, 1980; Baudin-Laurencin and Germon, 1987; Kanno et al., 1989). In post-larvae $(0.2 \mathrm{~g})$ of turbot experimentally infected by bathing with $V$. pelagius, Villamil et al. (2003) observed swelling and necrosis of gill secondary lamellae, sloughing of intestinal mucosa and necrosis of haematopoietic tissue in the kidney. These observations seem to be a combination of the two preceding theories. In our study, $V$. anguillarum cells were located in the epidermis and gut of the larvae, associated to rotifers but not to the intestinal epithelium (Ø. Bergh, pers. comm.). The larvae showed little signs of enteritis, but the epidermis was severely affected. In severely affected larvae, bacteria in blood vessels were found demonstrating septicaemia. It is possible that the mode of action could be dependent on the age/gut development of the fish. Our results seem to confirm that mortality in very young larvae was higher when the pathogen was added to the water rather than by oral challenge. Nevertheless, in culture conditions the usual way of entry of Vibrio in larval tanks is live prey (Verdonck et al., 1997). Several studies have shown that the intestinal microflora of larvae from first feeding is more dependent on the microflora of the live food ingested than on the bacteria present in the water. This fact has been reported for turbot (Munro et al., 1993; Blanch et al., 1997; Reitan et al., 1998), Atlantic halibut (Hippoglossus hippoglossus) (Bergh, 1995), and sea bass (Sparus aurata) (Grisez et al., 1997). It is likely that Vibrio cells could proliferate in the faeces (digested and non digested rotifers) of the larvae, as reported by Olsson et al. (1998) in adults. Subsequently, the bacteria would increase the load of Vibrio in the water and penetrate into the skin and gills. However, other effects of the pathogen on the larval gut must not be discarded.

Appearance of $V$. anguillarum and other Vibrio in rotifer production tanks is not exceptional. From rotifer productions in two marine fish hatcheries (Greece and Spain), Verdonck et al. (1997) isolated 93 strains of Vibrio, from which 28 were $V$. anguillarum strains. Although presence of some strains of V. anguillarum coincided with mass mortalities in larvae, information on mortalities of rotifers in production tanks was not provided by the authors. However, it is known that crashes in rotifer cultures can be caused by changes in the microbiota (Hino, 1993). Yu et 
al. (1990) reported that a toxin produced by a $V$. alginolyticus strain reduced rotifer survivals. Similarly, in the present study, long-term maintenance of rotifers in suspensions of $V$. anguillarum $\left(10^{7}-10^{8} \mathrm{CFU} \mathrm{ml}{ }^{-1}\right)$ with supernatant leaded to a progressive decrease of rotifer population (Challenges R1 and R2). This implies that if we want to use rotifers as vectors to introduce $V$. anguillarum to a larvae culture, the incubation of the bacteria with rotifers must be performed in short periods of time. Apparently, $24 \mathrm{~h}$ seems to be safe for the rotifer B. plicatilis, achieving a level of $V$. anguillarum of about $10^{3} \mathrm{CFU}$ rotifer $^{-1}$. However, small rotifers (B. calcyflorus) were not able to survive under such conditions (100\% mortality). A bath of $3 \mathrm{~h}$ can be considered safe for the rotifers during the bio-encapsulation, assuring high bacterial load. It is noteworthy that we did not observe mortalities of infected rotifers at a short or medium term in the larval rearing tanks, even when supernatant of bacteria was also delivered to those tanks (treatment $\mathrm{W}+$ ). This can be masked to some extent by the partial water renewals applied, the consumption of rotifers by the larvae and the daily restitution of rotifer densities. Anyway, the levels of prey in the tanks were always adjusted in excess in order to make food available to larvae.

The microbiological study of the model showed no correlation between larval survival rates and the number of total bacteria present in the larval microflora. Based on the challenges L3a and L3b, at day 3 posthatching (just before first feeding), total bacteria level were low (about $10^{2} \mathrm{CFU}$ larva ${ }^{-1}$ ). A progressive increase occurred with development, reaching levels of $10^{5} \mathrm{CFU}$ larva $^{-1}$ in 9-days old larvae. These results are in accordance with the findings of other authors (Munro et al., 1993; Ringø and Vadstein, 1998; Makridis et al., 2000; Huys et al., 2001). It is known that Vibrio population is seriously underestimated plating directly onto TCBS agar. The counts of Vibrio on TCBS are much lower than the proportion of Vibrio identified from isolates on marine agar (Munro et al., 1993). This problem was solved in this study using a replica-plating method from MA onto TCBS plates (unpub. data). Applying this method, it was observed in challenges L3a and L3b, that Vibrio species were the dominant bacteria in the larval microbiota both in challenged and unchallenged larvae. It is in agreement with the observations of Munro et al. (1993) and Blanch et al. (1997). In addition, high mortalities in challenged larvae (treatment R+) were found to occur about days 5-7, when the level of V. anguillarum in the larvae was noticeable.

The parameters obtained from the adjustment of the pooled data from experiments L2, L3a, L3b and L3c to the proposed logistical model confirmed the effectiveness of the model for experimental infections with $V$. anguillarum in turbot larvae (Fig. 4). The value of the asymptote or maximum final mortality in larvae infected with Vibrio was higher $(K(\mathrm{R}+)=72.70 \%)$ than in controls $(K(\mathrm{C})=41.57 \%)$. The same applies to specific mortality rates $\left(r_{m}(\mathrm{R}+)=1.34\right.$ 
and $r_{m}(\mathrm{C})=1.16$ days $^{-1}$, respectively). It is important to point out that despite the fact that the present study has been focussed on one serotype of $V$. anguillarum, the model of infection has also been successfully applied for experimental infections of turbot larvae with V. splendidus DMC-1 (H. Birkbeck, pers. comm.).

Other authors have used axenic rotifers as a tool for oral challenges with pathogens in turbot larvae (Munro et al., 1995). Our study is the first one in which first feeding turbot larvae were challenged with $V$. anguillarum under normal (non-axenic) hatchery conditions. The model proposed here for in vivo infections of turbot larvae with nonwashed V. anguillarum (bacteria + supernatant) through short-term incorporation in rotifers, is satisfactory for experimental purposes. The delivery of rotifers infected with $V$. anguillarum reproduced a typical mortality pattern in larvae (Person le Ruyet, 1989). with final mortalities ranging from 56 and $72 \%$ with respect to unchallenged larvae. This range is reasonable adequate since very high mortalities are not convenient to assure the viability of the experiments. However, the model can be modified according to the experimental needs. Delivery of the bacteria both into the water and rotifers would increase mortalities whereas a reduction in the number of deliveries of infected rotifers would increase survivals.

\section{ACKNOWLEDGEMENTS}

This work was supported by funds of the European Commission (Project PROBE, contract no. Q5RS-2000-31457). Dr. J.A. Vázquez had a postdoctoral contract (CSIC-I3P-PC 2003) financed by the European Social Fund. We thank Dr. Harry Birkbeck and Dr. Hazel Duncan for providing a culture collection strain of V. anguillarum and the conduction of agglutination test MONO-VA. We are grateful to Alicia Abalo and Rocío Rendo for technical support in the larval rearings and microbiological analyses. Stolt Sea Farm (Galice, Spain) provided turbot larvae and juveniles for conducting the experiments. M. Pérez-Lorenzo was granted by the Xunta de Galicia (Spain).

\section{REFERENCES}

Amend, D.,1981. Potency testing of fish vaccines. Dev Biol. Stand 49, 447-454.

Austin, B., Stuckey, L.F., Robertson, P.A.W., Effendi, I., Griffith, D.R.W., 1995. A probiotic strain of Vibrio algynoliticus effective in reducing diseases caused by Aeromonas salmonicida, Vibrio anguillarum and Vibrio ordalii. J. Fish Dis. 18, 93-96. 
Baudin-Laurencin, F., Germon, E., 1987. Experimental infection of rainbow trout, Salmo gairneri R., by dipping in suspensions of Vibrio anguillarum: ways of bacterial penetration; influence of temperature and salinity. Aquaculture 67, 203-205.

Bergh, Ø., 1995. Bacteria associated with early life stages of halibut, Hippoglossus hippoglossus L., inhibit growth of a pathogenic Vibrio sp. J. Fish Dis. 18, 31-40.

Blanch, A.R., Alsina, M., Simon, M., Jofre, J., 1997. Determination of bacteria associated with reared turbot (Scophthalmus maximus) larvae. J. Appl. Microbiol 82, 729-734.

Chair, M., Dehasque, M., Van Poucke, S., Nelis, H., Sorgeloos, P., De Leenheer, A.P., 1994. An oral challenge for turbot with Vibrio anguillarum. Aquacult. Int. 2, 270-272.

Chart, H., Munn, C.B., 1980. Experimental vibriosis in the eel (Anguilla anguilla). In: Ahne, W. (Eds.), Fish Diseases, Heidelberg, Springer, pp. 39-44.

De la Cruz, M., Muroga, K., 1989. The effects of Vibrio anguillarum extracellular products on Japanese eels. Aquaculture 80, 201-210.

Diggles, B.K., Carson, J., Hine, P.M., Hickman, R.W., Tait, M.J., 2000. Vibrio species associated with mortalities in hatchery-reared turbot (Colistium nudipinnis) and brill (C. guntheri) in New Zealand. Aquaculture 183, 1-12.

Egidius, E., 1987. Vibriosis: pathogenicity and pathology. A review. Aquaculture 67, 15-28.

EU, Cump, 1993. Guidance for vaccines intended for fish. Commission of the European Communities III/3590/92/EN, pp. 9.

Grisez, L., Chair, M., Sorgeloos, P., Ollevier, F., 1996. Mode of infection and spread of Vibrio anguillarum in turbot Scophthalmus maximus larvae after oral challenge through live feed. Dis. Aquat. Org. 26, 181-187.

Grisez, L., Reyniers, J., Verdonck, L., Swings, J., Ollevier, F., 1997. Dominant intestinal microflora of sea bream and sea bass larvae, from two hatcheries, during larval development. Aquaculture 155, 387-399.

Hino, A., 1993. Present culture systems of the rotifer (Brachionus plicatilis) and the function of microorganisms. In: Lee, S.C., Su, M.S., Liao, I.L. (Eds.), Proc. Finfish Hatchery in Asia, 91, 17-19.

Hjelm, M., Bergh, Ø., Riaza, J., Nielsen, J., Melchiorsen, J., Jensen, S., Duncan, H., Ahrens, P., Birkbeck, H., Gram, L., 2004. Selection and identification of autochthonous potential probiotic bacteria from turbot larvae (Scophthalmus maximus) rearing units. Appl. Environ. Microbiol. 61(4): 1540-1545. 
Horne, M.T., Richards, R.H., Roberts, R.J., Smith, P.C., 1977. Peracute vibriosis in juvenile turbot Scophthalmus maximus. J. Fish Biol. 11, 355-361.

Huys, L., Dhert, P., Robles, R., Ollevier, F., Sorgeloos, P., Swings, J., 2001. Search for beneficial bacterial strains for turbot (Scophthalmus maximus L.) larviculture. Aquaculture 193, 25-37.

Kanno, T., Yasunoby, H., Okada, N., Muroga, K., 1989. Mode of transmission of vibriosis among ayu Plecoglossus altivelis. J. Aquat. Anim. Health 1, 2-6.

Larsen, J.L., Pedersen, K., Dalsgaard, I., 1994. Vibrio anguillarum serovars associated with vibriosis in fish. J. Fish Dis. 17: 259-267.

Lee, H.K., Kim, H.J., Kim, I., 1991. Isolation of Vibrio species from cultured flounders (Paralichthys olivaceus) with ulcers and ascites in the southern coast of Korea during the winter season. Korean J. Microbiol. 29, 319-328. Lupiani, B., Dopazo, C.P., Ledo, A., Fouz, B., Barja, J.L., 1989. New syndrome of mixed bacterial and viral etiology in cultured turbot Scophthalmus maximus. J. Aquat. Anim. Health 1, 197-204.

Makridis, P., Fjellheim, A.J., Skjermo, J., Vadstein, O., 2000. Colonization of the gut in first feeding turbot by bacterial strains added to the water or bioencapsulated in rotifers. Aquacult. Int. 8, 367-380.

Masumura, K., Yasunobu, H., Okada, N., Muroga, K., 1989. Isolation of Vibrio sp, the causative bacterium of intestinal necrosis of Japanese flounder larvae. Fish Pathol. 24(3), 135-141.

Munro, P.D., Barbour, A., Birkbeck, T.H., 1995. Comparison of the growth and survival of larval turbot in the absence of culturable bacteria with those in the presence of Vibrio anguillarum, Vibrio alginolyticus, or a Marine Aeromonas sp. Appl. Environ. Microbiol. 61, 4425-4428.

Munro, P.D., Birkbeck, T.H., Barbour, A., 1993. Influence of rate of bacterial colonisation of the gut of turbot larvae on larval survival. In: Reinertsen, H., Dahle, L.A., Jørgensen, L., Tvinnereim, K. (Eds.), Fish Farming Technology. A.A. Balkema, Rotterdam, pp. 85-92.

Muroga, K., Higashi, M., Keetoku, H., 1987. The isolation of intestinal microflora of farmed red seabream (Pagrus major) and black seabream (Acanthopagrus schlegeli) at larval and juvenile stages. Aquaculture 65, 79-88.

Muroga, K., Yasunobu, H., Okada, N., Masumara, K., 1990. Bacterial enteritis of cultured flounder Paralichthys olivaceus larvae. Dis. Aquat. Org. 9, 121-125. 
Myhr, E., Larsen, J.L., Lillehaug, A., Gudding, R., Heum, M., Hastein, T., 1991. Characterization of Vibrio anguillarum and closely related species isolated from farmed fish in Norway. Appl. Environ. Microbiol. 57, 27502757.

Olsson, J.C., Joborn, A., Westerdahl, A., Blomberg, L., Kjelleberg, S., Conway, P.L., 1996. Is the turbot, Scophthalmus maximus (L), intestine a portal of entry for the fish pathogen Vibrio anguillarum?. J. Fish Dis. 19(3), 225-234.

Person Le Ruyet, J., 1989. The hatchery rearing of turbot larvae (Scophthalmus maximus). Cuad. Area Cienc. Mar. Semin. Estud. Galegos 3: 57-91.

Reitan, K I., Natvik, C.M., Vadstein, O., 1998. Drinking rate, uptake of bacteria and microalgae in turbot larvae. J. Fish Biol. 53, 1145-1154.

Ringø, E., Vadstein, O., 1998. Colonization of Vibrio Pelagius and Aeromonas caviae in early developing turbot (Scophthalmus maximus L.) larvae. J. Appl. Microbiol. 84, 227-233.

Roque, A., Turnbull, J.F., Escalante, G., Gómez-Gil, B., Alday-Sanz, M.V., 1998. Development of a bath challenge for the marine shrimp Penaeus vannamei Boone, 1931. Aquaculture 169, 283-290.

Santos, Y., Bandín, I., Núñez, S., Montero, M., Silva, A., Toranzo, E., 1992. Comparison of extracellular biological activities of Vibrio anguillarum and Aeromonas hydrophila. Aquaculture 107, 259-270.

Scott, J.M., 1980. Effect of growth rate of the food alga on the growth/ingestion efficiency of a marine herbivore. J. Mar. Biol. Assoc. UK 60, 681-702.

Skov, M.N., Pedersen, K., Larsen, J.L., 1995. Comparison of pulsed-field gel electrophoresis, ribotyping and plasmid profiling for typing of Vibrio anguillarum serovar O1. Appl. Environ. Microbiol. 61, 1540-1545.

Toranzo, A.E., Santos, Y., Lemos, M.L., Ledo, A., Bolinches, J., 1987. Homology of Vibrio anguillarum strains causing epizootics in turbot, salmon and trout reared on Atlantic coast of Spain. Aquaculture 67, 41-52.

Toranzo, A.E., Santos, Y., Bandín, I., Romalde, J.L., Ledo, A., 1990. Five year survey of bacterial fish infection in continental and marine aquaculture in northwest Spain. World Aquacult. 21, 91-94.

Toranzo, A.E., Barja, J.L., 1990. A review of the taxonomy and sero-epizootiology of Vibrio anguillarum, with special reference to aquaculture in the northwest of Spain. Dis. Aquat. Org. 9, 73-82. 
Toranzo, A.E., Novoa, B., Romalde, J.L., Núñez, S., Devesa, S., Mariño, E., Silva, R., Martínez, E., Figueras, A., Barja, J.L., 1993. Microflora associated with healthy and diseased turbot (Scophthalmus maximus) from three farms in northwest Spain. Aquaculture 114, 189-202.

Toranzo, A.E., Barja, J.L., Devesa, S., 1994. An overview of the main infectious problems in cultured turbot: present status and future necessities. EAS Spec. Pub. 22, 106-126.

Verdonck, L., Grisez, L., Sweetman, E., Minkoff, G., Sorgeloos, P., Ollevier, F., Swings, J., 1997. Vibrios associated with routine productions of Brachionus plicatilis. Aquaculture 149, 203-214.

Villamil, L., 2002. Aplicación de las bacterias lácticas en el cultivo del rodaballo (Scophthalmus maximus L.). PhD thesis University of Vigo (Spain), 211 p.

Villamil, L., Figueras, A., Toranzo, A.E., Planas, M., Novoa, B., 2003. Isolation of a highly pathogenic Vibrio pelagius strain associated with mass mortalities of turbot, Scophthalmus maximus (L.), larvae. J. Fish Dis. 26, 293303.

Yu, J.P., Hino, A., Noguchi, T., Wakabayashi, H., 1990. Toxicity of Vibrio alginolyticus on the survival of the rotifer Brachionus plicatilis. Nippon Suisan Gakkaishi 56, 1455-1460. 
Table 1: Challenge L. Experimental conditions of the challenges performed for infection of turbot larvae with $V$. anguillarum. Control: No bacteria added. W: Vibrio added into the water of the larval tanks. W+: Vibrio and supernatant added into the water. $\mathrm{R}+$ : Rotifers bathed in Vibrio and supernatant. First feeding of larvae: day 3 post hatching.

\begin{tabular}{|c|c|c|c|c|}
\hline \multirow[b]{2}{*}{ Treatments } & \multicolumn{3}{|c|}{ Delivery of Vibrio anguillarum to turbot larvae } & \multirow[b]{2}{*}{ Days } \\
\hline & via rotifers & Days & via water & \\
\hline \multicolumn{5}{|c|}{ Challenge L1 } \\
\hline \multicolumn{5}{|c|}{ Control } \\
\hline $\mathrm{W}$ & & & $10^{6} \mathrm{CFU} \mathrm{ml} \mathrm{l}^{-1}$ & 3 \\
\hline \multicolumn{5}{|c|}{ Challenge L2 } \\
\hline \multicolumn{5}{|c|}{ Control } \\
\hline $\mathrm{R}+$ & $10^{8} \mathrm{CFU} \mathrm{ml}^{-1 * *}$ & $3,5,7$ & & \\
\hline $\mathrm{R}+\mathrm{W}+$ & $10^{8} \mathrm{CFU} \mathrm{ml}^{-1 * *}$ & $3,5,7$ & $10^{7} \mathrm{CFU} \mathrm{m} \mathrm{m}^{-1 * *}$ & $3,5,7$ \\
\hline \multicolumn{5}{|c|}{ Challenge L3a-L3c } \\
\hline Control & & & & \\
\hline $\mathrm{R}+$ & $10^{8} \mathrm{CFU} \mathrm{ml} \mathrm{l}^{-* *}$ & $4,6,8$ & & \\
\hline
\end{tabular}

Table 2: Challenge S - Survivals and final dry weights $\left(\mu\right.$ larva $\left.^{-1}\right)$ at day 10 in the challenge performed to verify the effect of supernatant of $V$. anguillarum cultures in turbot larvae. Control: No bacteria added. R: Rotifers bathed in Vibrio. R+: Rotifers bathed in Vibrio and supernatant. First feeding: day 3 post hatching. Means \pm SD. Different letters mean significant differences (SNK test: $\mathrm{p}<0.05$ ) between treatments (ANOVA: survival $\mathrm{p}=0.001$, weight $\mathrm{p}=0.049$ ).

\begin{tabular}{cccc}
\hline Treatments & $\begin{array}{c}\text { \% SURVIVAL } \\
\text { Absolute }\end{array}$ & $\begin{array}{c}\text { \% SURVIVAL } \\
\text { Relative to control }\end{array}$ & $\begin{array}{c}\text { DRY WEIGHT } \\
\mu \mathrm{g} / \text { larva }\end{array}$ \\
\hline Control & $79 \pm 6^{\mathrm{a}}$ & 100 & $92 \pm 3^{\mathrm{a}}$ \\
$\mathrm{R}$ & $58 \pm 3^{\mathrm{b}}$ & 73 & $95 \pm 14^{\mathrm{a}}$ \\
$\mathrm{R}+$ & $35 \pm 2^{\mathrm{c}}$ & 44 & $70 \pm 1^{\mathrm{b}}$ \\
\hline
\end{tabular}


Table 3: Challenge L - Survivals and final dry weights $\left(\mu\right.$ larva $\left.^{-1}\right)$ in the challenges performed for infection of turbot larvae with $V$. anguillarum. First feeding: day 3 post hatching. Control: No bacteria added. W: Vibrio added into the water of the larval tanks. W+: Vibrio and supernatant added into the water. R+: Rotifers bathed in Vibrio and supernatant. Means \pm SD. Within each challenge, different letters mean significant differences (SNK test: $\mathrm{p}<0.05$ ) between treatments.

\begin{tabular}{|c|c|c|c|c|c|}
\hline & Days & Treatments & $\begin{array}{c}\text { \% SURVIVAL } \\
\text { Absolute }\end{array}$ & $\begin{array}{c}\text { \% SURVIVAL } \\
\text { Relative to control }\end{array}$ & $\begin{array}{c}\text { DRY WEIGHT } \\
\mu \mathrm{g} / \text { larva }\end{array}$ \\
\hline \multirow{2}{*}{ Challenge L1 } & $3-10$ & Control & $80 \pm 4^{\mathrm{a}}$ & 100 & $97 \pm 5^{\mathrm{a}}$ \\
\hline & & $\mathrm{W}$ & $42 \pm 47^{\mathrm{a}}$ & 52 & $88 \pm 19^{a}$ \\
\hline \multirow[t]{3}{*}{ Challenge L2 } & $3-9$ & Control & $57 \pm 26^{a}$ & 100 & $69 \pm 10^{a}$ \\
\hline & & $\mathrm{R}+$ & $24 \pm 5^{\mathrm{a}}$ & 42 & $64 \pm 3^{\mathrm{a}}$ \\
\hline & & $\mathrm{R}+\mathrm{W}+$ & $6 \pm 2^{b}$ & 11 & $56 \pm 5^{\mathrm{a}}$ \\
\hline \multirow[t]{2}{*}{ Challenge L3a } & $3-14$ & Control & $34 \pm 13^{\mathrm{a}}$ & 100 & $337 \pm 13^{a}$ \\
\hline & & $\mathrm{R}+$ & $15 \pm 8^{\mathrm{a}}$ & 44 & $388 \pm 110^{\mathrm{a}}$ \\
\hline \multirow[t]{2}{*}{ Challenge L3b } & $3-8$ & Control & $29 \pm 1^{a}$ & 100 & $40 \pm 3^{\mathrm{a}}$ \\
\hline & & $\mathrm{R}+$ & $8 \pm 0^{b}$ & 28 & $37 \pm 2^{\mathrm{a}}$ \\
\hline \multirow[t]{2}{*}{ Challenge L3c } & $3-10$ & Control & $32 \pm 1^{\text {a }}$ & 100 & $121 \pm 0^{\mathrm{a}}$ \\
\hline & & $\mathrm{R}+$ & $10 \pm 0^{\mathrm{b}}$ & 31 & $101 \pm 9^{\mathrm{a}}$ \\
\hline
\end{tabular}

Table 4: Challenge L - Changes with time in the level of Vibrio anguillarum in the water of the larval rearing tanks $\left(\log \mathrm{CFU} \mathrm{ml}{ }^{-1}\right.$ ) and in turbot larvae (log CFU larva $\left.{ }^{-1}\right)$. W: Vibrio added into the water of the larval tanks. W+: Vibrio and supernatant added into the water. R+: Rotifers bathed in Vibrio and supernatant. First feeding of larvae: day 3 post hatching.

\begin{tabular}{|c|c|c|c|c|c|c|c|}
\hline & \multicolumn{4}{|c|}{ WATER (log cfu ml ${ }^{-1}$ ) } & \multicolumn{3}{|c|}{ LARVAE (log cfu larvae ${ }^{-1}$ ) } \\
\hline & Day & W & $\mathrm{R}+$ & $\mathrm{R}+\mathrm{W}+$ & W & $\mathrm{R}+$ & $\mathrm{R}+\mathrm{W}+$ \\
\hline \multirow[t]{5}{*}{ Challenge L1 } & 3 & 6.0 & & & 0.0 & & \\
\hline & 4 & 3.5 & & & 0.9 & & \\
\hline & 6 & 1.4 & & & 0.0 & & \\
\hline & 7 & 0.0 & & & 0.0 & & \\
\hline & 9 & 0.0 & & & 0.0 & & \\
\hline \multirow[t]{4}{*}{ Challenge L2 } & 3 & & 0.0 & 7.0 & & 0.0 & 0.0 \\
\hline & 4 & & 3.8 & 5.3 & & 1.8 & 1.1 \\
\hline & 6 & & 0.0 & 3.7 & & 0.0 & 0.0 \\
\hline & 8 & & 0.0 & 2.9 & & 0.0 & 0.0 \\
\hline \multirow[t]{4}{*}{ Challenge L3a } & 3 & & 0.0 & & & 0.0 & \\
\hline & 5 & & 4.0 & & & 2.9 & \\
\hline & 7 & & 2.6 & & & 2.9 & \\
\hline & 9 & & 3.6 & & & 2.9 & \\
\hline \multirow[t]{3}{*}{ Challenge L3b } & 3 & & 0.0 & & & 0.0 & \\
\hline & 5 & & 3.2 & & & 0.0 & \\
\hline & 7 & & 3.6 & & & 2.9 & \\
\hline
\end{tabular}




\section{LIST OF FIGURES}

Fig. 1 Challenge S - Accumulated mortalities in the challenge performed to verify the effect of the supernatant of $V$. anguillarum cultures in turbot larvae. Control: No bacteria added. R: Rotifers bathed in Vibrio. R+: Rotifers bathed in Vibrio and supernatant. First feeding: day 3 posthatching. Means \pm SD.

Fig. 2 Challenge $S$ - Total bacteria, total Vibrio and $V$. anguillarum in the water of larval rearing tanks and in turbot larvae (day 9 posthatching). Control: No bacteria added. R: Rotifers bathed in Vibrio. R+: Rotifers bathed in Vibrio and supernatant. First feeding: day 3 posthatching. Means (2 parallel tanks) \pm SD.

Fig. 3 Relationship between the final survivals in not infected larvae (control) and in larvae infected with Vibrio + supernatant via rotifers $(\mathrm{R}+)$. Survivals of challenged larvae are absolute or relative to controls (\%). Data from challenges L2, 3a, 3b and 3c.

Fig. 4 Challenges L2, L3a, 3b and 3c - Above: Cumulative mortalities of turbot larvae. Control: black symbols. Infected larvae: white symbols. Means \pm SD. Original data fitted to a modified logistic model (continuous line). Below: Experimental means (pooled data of all challenges) with confidence intervals $(\alpha=0 \cdot 20 ; v=3)$. First feeding: day 3 posthatching. C: control (no bacteria added). R+: Rotifers bathed in Vibrio and supernatant. $K$ (maximum mortality). 


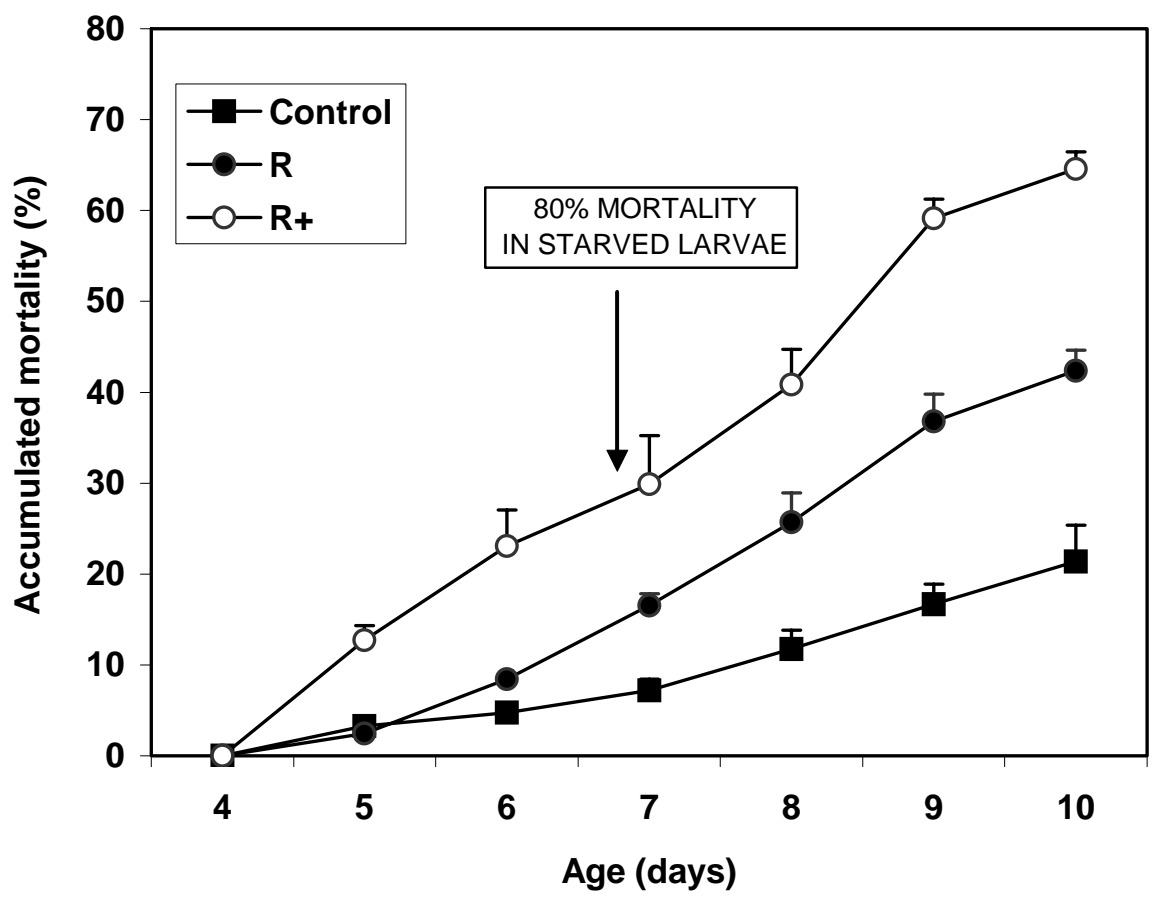

Fig. 1

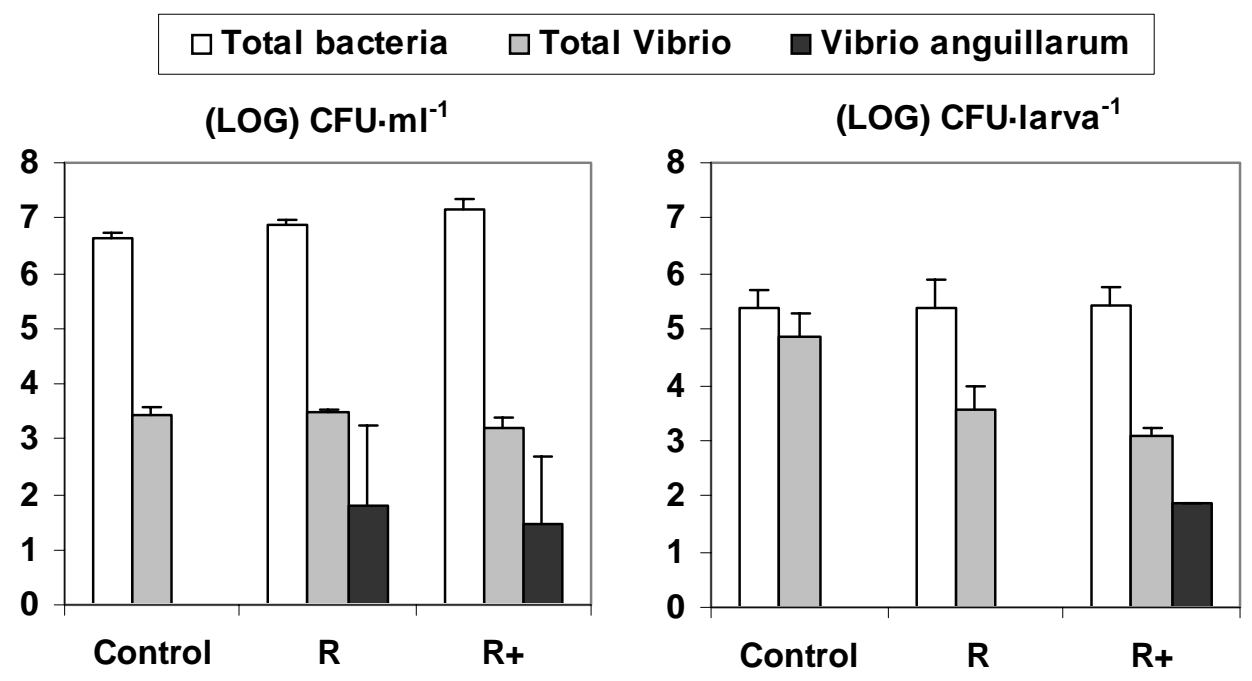

Fig. 2 


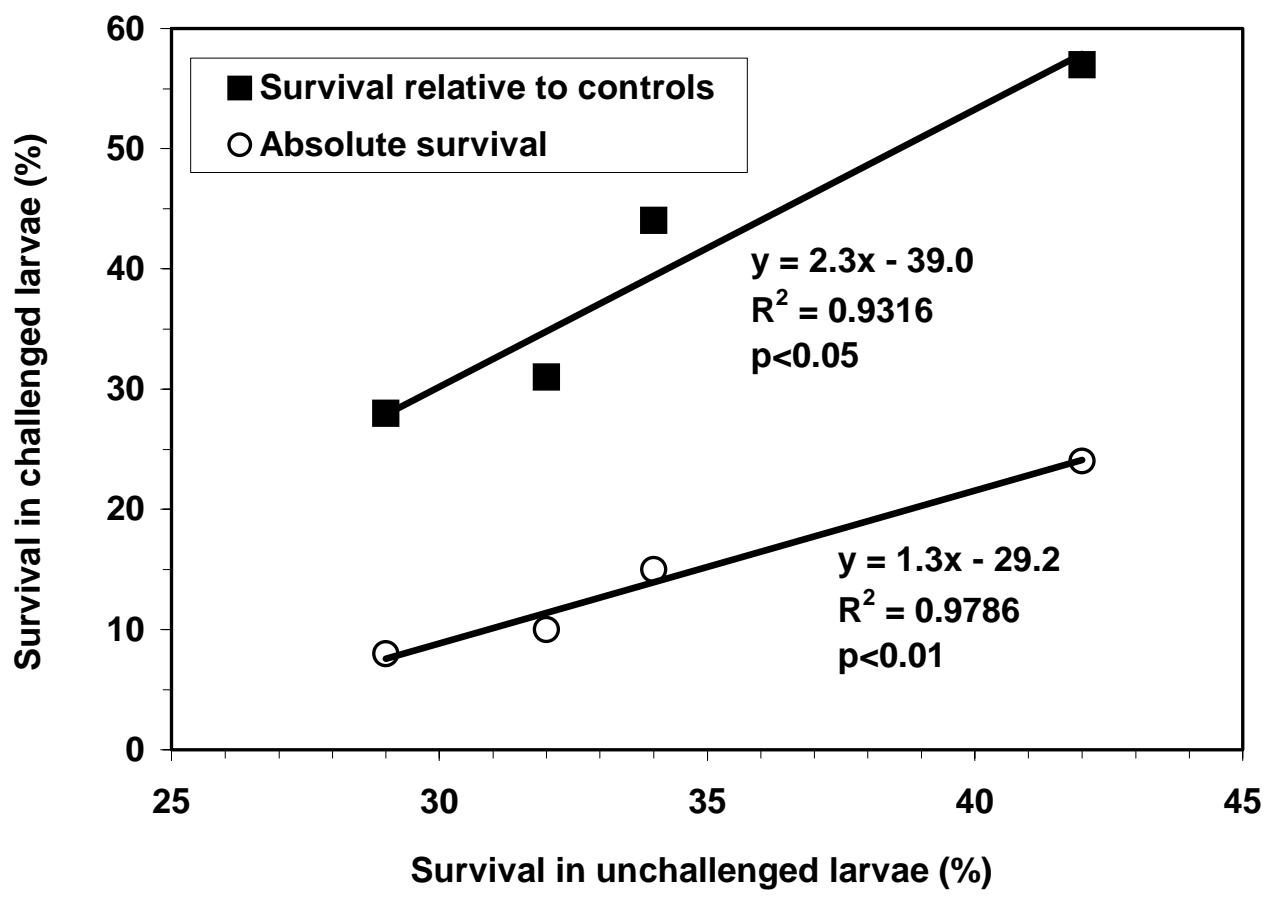

Fig. 3 

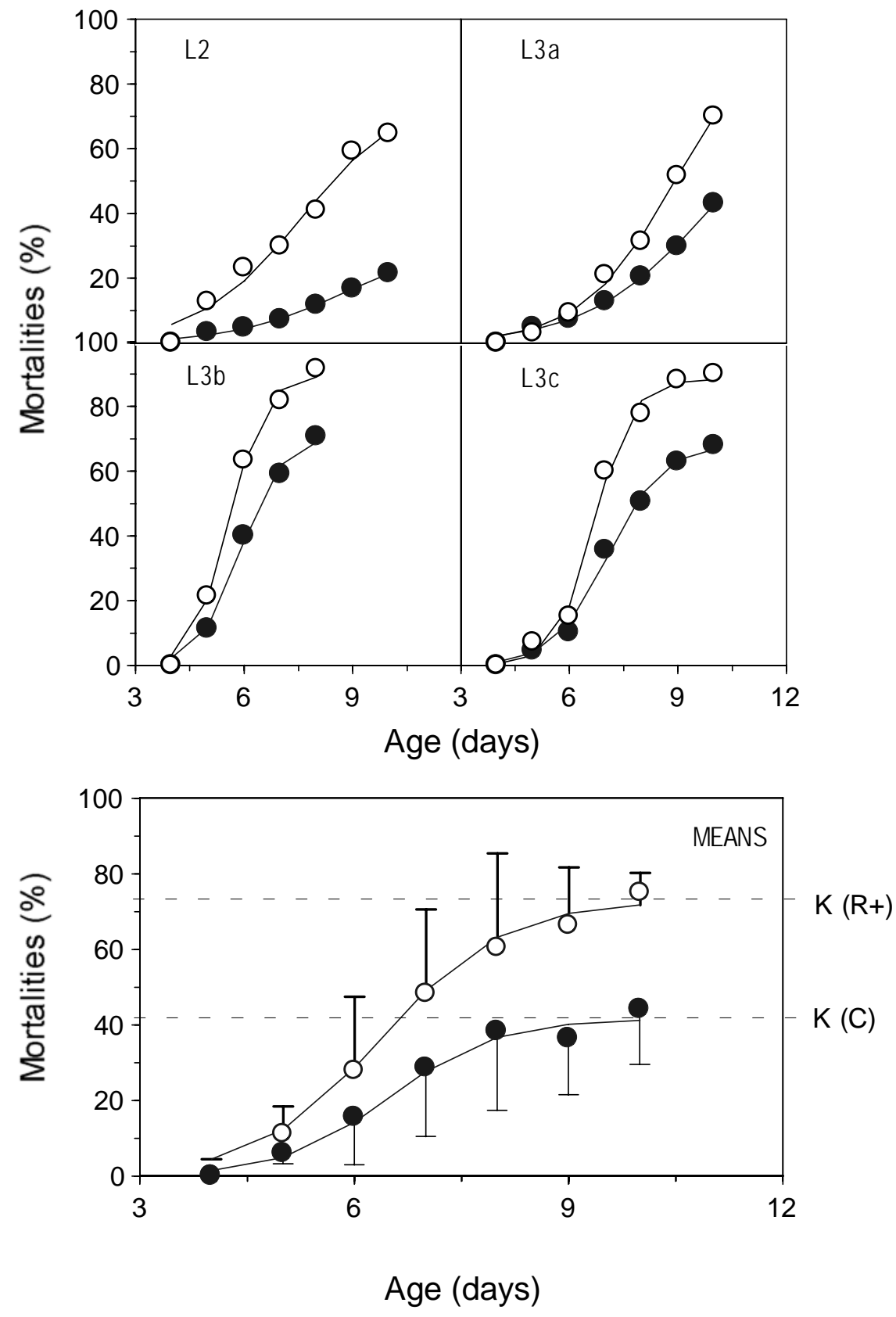

Fig. 4 